the authors take up the enzymology of signal transduction in the nervous system. The failure to deal earlier with ATP-linked reactions is mitigated here in the description of the sodium-potassium ion pump. Alzheimer's disease, nerve gases, the McNaghten Rules, are all brought into a rousing climax.

Discovering Enzymes can safely be recommended to anyone, undergraduate upwards, who wishes to become acquainted with the current excitement in the field of molecular enzymology, though it lacks the breadth of coverage to fit that bill on its own. One or two small quibbles: the strength of an

\section{Modern shamans}

\section{Alison Jolly}

Walking with the Great Apes. By Sy Montgomery. Houghton: 1991. Pp.280. $\$ 19.95$.

JANE Goodall, Dian Fossey and Biruté Galdikas have transformed our knowledge of chimpanzees, orangutans and gorillas - and with it our view of women's place in nature. In her joint biography, Walking with the Great Apes, Sy Montgomery traces three extraordinary lives. But she does more than tell their story; she tries to show that these three women are not scientists but modern shamans who reach out with an emotional current to the wild. She reveals the empathy, even the love, one must feel to spend decades with wild creatures, but is she right that science and love exclude each other?

The book has lively, lucid writing, and is constructed as a three-part fugue. Montgomery balances tact and openness, and respect without adulation. To me she too often knows what her subjects were thinking 20 years ago, or just what emotion is mirrored in an ape's eyes, but mostly this is a fine read.

She brings out well the differences between the three. Jane Goodall's "westernness stands out like a porcelain tea-cup on a rough-hewn treestump". To judge from her story, though, Goodall's true mettle must be more like high-strength titanium, especially now in her crusade for the humane treatment of chimpanzees that have fallen into human hands. Galdikas makes her home in the swampy Bornean rainforest she compares to "the original Garden of Eden". She lives with her Dayak Indonesian husband, two of her children, a dozen or more ex-captive orangutans, Dayak guides, American Earthwatch volunteers and Indonesian graduate stu- ionic bond is not the same as the force between two point charges; the velocitysubstrate concentration plots, as drawn, are not rectangular hyperbolae; and it will sow confusion if amino-acid residues in proteins are referred to as subunits. Perhaps it is best summed up as that miracle of rare device, a coffee-table book on enzymes; it should fulfil a useful purpose in presenting a major area of the life sciences in a colourful and attractive way to a wider public.

Richard Perham is in the Department of Biochemistry, University of Cambridge, Tennis Court Road, Cambridge CB2 1QW, UK.

dents. As for Dian Fossey, Louis Leakey said years before her murder, "Her life was a tragedy, and will always be a tragedy". She was tragic in the Greek sense, not as a person to pity, but as a hero whose own power entailed her downfall.

Is Montgomery right that these three are not scientists, but shamans? In a revealing preface, Montgomery describes her own study of three young emus, Australian birds tall enough to look a woman in the eye. With minds so alien, she could not delude herself into even the partial empathy we feel for apes. Yet Montgomery realized that what might be thought a respectable sum for a male scientist teaching on two continents, running a major research camp five hours' boat-ride into the rainforest, and incidentally mothering small children. Even Fossey, with her tortured warfare in defence of her gorillas, published a book and journal articles which will stand for years to come.

In her latest book, Through a Window (for review see Nature 348, 371; 1990), Goodall tells how she went to Gombe to recover from her second husband's death. In that time she came "intuitively ... closer to the chimpanzees than ever before. For I was with them not to observe, to learn, but simply because I needed their company, undemanding and free of pity." That makes Montgomery's point: communion with nature goes far deeper and broader than the scientific attitude. It makes mine as well, that for 20 years before, and ten since, Goodall has gone notebook in hand, observing, thinking as well as feeling.

A different interpretation is that these three have led a paradigm shift in the study of animal behaviour. Goodall's insistence on the importance of the individual has now been accepted in primate studies, and resonates out into further and further fields. Kuhn showed us that such a paradigm shift is al-

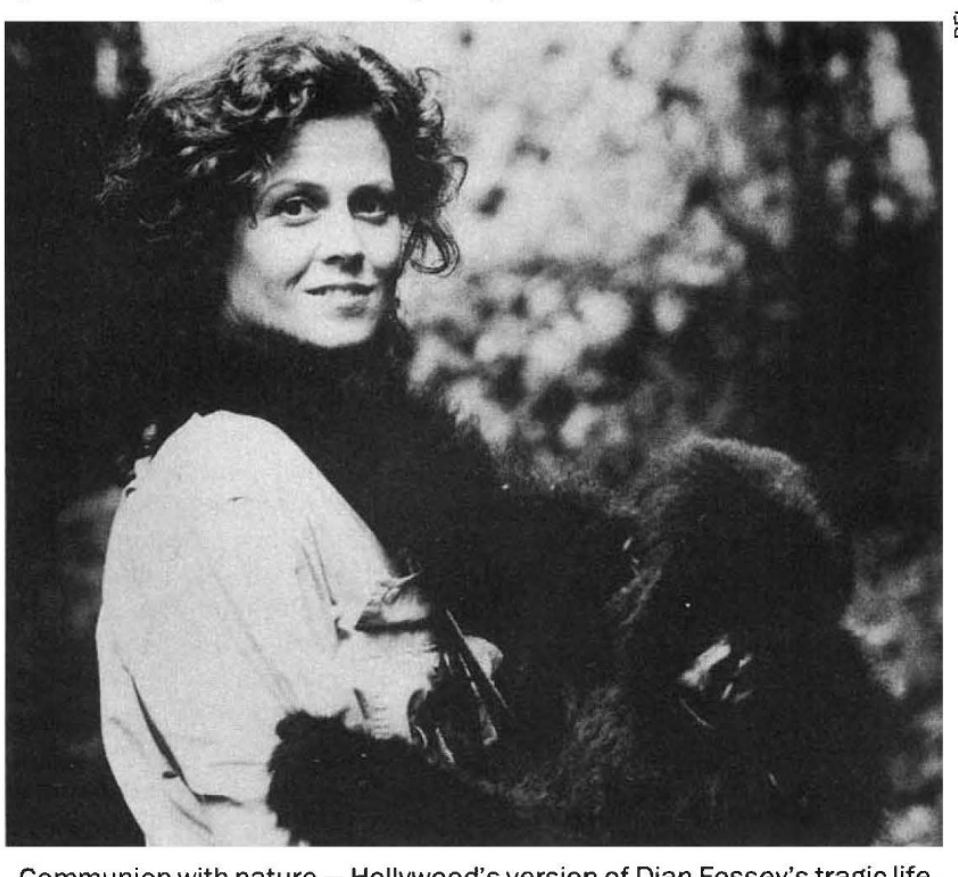

with nature - Hollywood's version of Dian Foss
she felt for the birds was love - a special kind of love that has no basis in dependency, no expectation of return. It is this love, this communion she attributes to Goodall, Fossey and Galdikas.

Right. But then she spoils it by undervaluing their scientific contribution. She repeats disparaging (and unjustified) remarks about Goodall's Cambridge thesis. She only once mentions the 25-year monumental monograph The Chimpanzees of Gombe (Harvard University Press, 1986). She cites Galdikas as having only 40 publications, and that her one book so far is in Indonesian. This selves. ways resisted - but that it is an integral part of science, not a renunciation of science. Montgomery also quotes praise, concluding, "Jane's work has ushered in the glimmerings of a new way of doing science, a scientific outlook that draws upon the feminine emphasis upon individuality, relationships, and empathy".

Much is now written about women's science as different from men's. This may be so. But I suspect that an accurately attuned feeling for the organism will turn out to be not just female science, but good science. The important thing is not to lose either thought or feeling in an artificial dichotomy. In this present world, we humans threaten the survival of wild ecosystems and wild creatures including the great apes, our nearest relatives. We are only just realizing how dependent even our own species is upon a fragile biosphere. We desperately need modern shamans: wise women and wise men. Our modern shamans, to be most effective, must also be scientists. If we insist on a dichotomy and champion either blind emotion or sterilized intellect, we risk deliberately letting go of our lifeline to survival - for the apes, or even for ourand Evolutionary Biology, Princeton University, Princeton, New Jersey 08544, USA. 